\title{
Science-Driven Societal Transformation, Part II: Motivation and Strategy
}

\author{
John C. Boik \\ Courtesy Faculty, Environmental Sciences Graduate Program, Oregon State University, \\ Corvallis, OR 97331, USA; boikj@oregonstate.edu
}

Received: 26 August 2020; Accepted: 22 September 2020; Published: 29 September 2020

\begin{abstract}
Climate change, biodiversity loss, and other well-known social and environmental problems pose grave risks. Progress has been insufficient, and as a result, scientists, global policy experts, and the general public increasingly conclude that bold change is required. At least two kinds of bold change are conceivable: reform of existing societal systems (e.g., financial, economic, and governance systems), including their institutions, policies, and priorities; and transformation, understood here as the de novo development of and migration to new and improved systems. The latter has barely been explored in the scientific literature and is the focus of this concept paper. The main theses explored are that transformation is prudent, given risks, attractive, given potential benefits, and achievable, given political, social, and financial constraints. A body of literature is cited in support, but that body is necessarily small given the novelty of the topic. In particular, there are almost no papers in the scientific literature addressing the "how to?" of transformation, a central theme of this paper. Thus, this paper serves in part to raise topics and bring attention to possibilities and new directions.
\end{abstract}

Keywords: societal transformation; systems change; sustainability; societal cognition; climate change; biodiversity loss; active inference; cooperation; SAILS

JEL Classification: B50; I3; O1; O30; P20; P41; P50; Q01; Q54; Q57

\section{Introduction}

Climate change, biodiversity loss, and other major unsolved problems pose serious social and ecological risks. Despite decades of warnings by the scientific community, nations, including the United States, have largely failed to take adequate steps to address root causes, reduce vulnerabilities, and mitigate risks [1,2]. The majority of past and current adaptation efforts have been incremental [3,4]. A growing body of scientific work and policy development suggests that incremental steps are insufficient to avoid catastrophe.

Frustrated with inadequate action, and aware that precious little time remains for a dramatic change in course, two complementary notions are gaining credence within the scientific, global policymaking, and public worlds. First, existing societal systems (e.g., economic, financial, and governance systems) are dysfunctional or maladaptive with regard to protecting human health and the environment (i.e., we face preventable catastrophe). Second, we are in need of bold change [4-19].

As one example, a 2018 special report from the United Nations Intergovernmental Panel on Climate Change (IPCC) warns that risks will rise sharply if global warming is allowed to exceed $1.5^{\circ} \mathrm{C}$ [20]. The authors conclude that while limiting warming to $1.5^{\circ} \mathrm{C}$ is not impossible, it would require unprecedented, far-reaching transitions in energy, land and urban infrastructure, and industrial systems. These span geophysical, ecological, technological, economic, sociocultural, and institutional dimensions, including issues of governance, poverty, inequality, sustainable development, and social justice. 
A second example is the 2019 Global Assessment from the UN Intergovernmental Science-Policy Platform on Biodiversity and Ecosystem Services (IPBES) [21]. It warns that about one million species currently face extinction and that without bold action the extinction rate will accelerate. The authors conclude that current national and global programs are insufficient and call for transformational change, which they define as "a fundamental, system-wide reorganization across technological, economic and social factors, including paradigms, goals and values".

Societal change can be classified as incremental, reformist, or transformational [16,22,23]. Using terms from the software development world, these are akin to updates (minor improvements), upgrades (major improvements or new versions), and migrations (the switch to new or different systems). Bold change then refers to reform, transformation, or both. The focus of this paper is transformation, viewed as a complement to reform. Here the terms societal transformation, systems change, and systems migration refer to a process of transition to fundamentally new societal systems, including new institutions, rules, policies, and priorities, that are developed de novo in a science-driven (evidence-based) research and development process using modern tools and approaches.

Societal systems are broadly defined here as nearly all aspects of societal organization (beyond the family level) that involve collective learning, decision making, and adaptation. Thus, societal systems cover nearly every system of societal self-organization, including the six overarching ones, summarized as economic, governance, legal, health, analytical, and education systems [24]. The economic systems category, for example, includes monetary and financial systems. Societal systems also include their associated institutions, rules, and policies, and the coevolving social-cultural components (beliefs, values, norms, and worldviews) that shape and are shaped by systems. Existing systems (those in use by societies today) are called native systems.

Society refers here to any sizable scale of social organization, from the local community up through city, region, nation, and world. Local community refers to a fraction of an urban or rural population, roughly 1000 people or more. A local community can be, but is not necessarily (or usually), a formal political body, such as a city.

This concept paper is the second in a series of three that together describe the foundations for a novel science-driven research and development program aimed at societal transformation. The first paper provides definitions, aims, core hypotheses, and a worldview [24]. This one builds on the first to discuss motivations for transformation, the role of science in transformation, a theory of change by which transformation might be achieved, and fitness metrics by which the quality of new system designs might be assessed. The last paper in the series discusses system design [25].

While some work has pointed to the need for bold change (including the UN reports just mentioned), the distinction between reform and transformation as paths to change has barely been discussed in the literature. For those few papers that mention transformation, the "how to?" (of development, testing, implementation, etc.) remains largely untouched, as do goals and criteria for success. Likewise, while a limited number of academic, civic, and other programs critique current systems and programs, focus on the need for bold change, or study and support grassroots efforts aimed at change [26-31], to my knowledge, this series is the first description in the literature of a viable, science-driven R\&D program that aims to tackle the research, development, testing, implementation, monitoring, and improvement of new, integrated systems. The significance of this paper is that it raises issues and starts a discussion aimed directly at the "how to?" of societal transformation, and it establishes a record and criteria by which future R\&D proposals aimed at transformation might be contrasted. Beyond this, the particular R\&D program described here could eventually prove useful in achieving transformation. As such, this paper has potential for massive impact.

Sections 2 and 3 summarize the literature in support of the thesis that transformation is prudent, given risks, and attractive, given potential benefits. This literature was collected largely through Google Search, Google Scholar, and PubMed using search terms such as societal transformation, climate change, biodiversity loss, systems change, systems reform, societal risk, and societal change. Focus was on the period of 2016 to the present. Selected references of retrieved articles were explored. 
These two sections do not constitute a formal literature review, however, but rather use existing literature to build a narrative in support of the theses. The narrative is consistent with the view of societal systems as the cognitive architecture of a society, and their normative role in achieving and maintaining vitality, as discussed in Part I of this series [24]. Potential benefits of new systems stem from improved societal cognition, including greater cooperation and improved capacity for learning, problem solving, and adaptation.

To convincingly show that transformation is beneficial and attractive would require evidence. Such evidence could come in the form of computer simulations and other studies, ideally accompanied by data gathered during the testing of new systems in real-world settings. While an initial simulation study has been published illustrating the function and benefits of an idealized, prototypical local economic system [32], to date there are no new societal systems in operation or testing of the kind envisioned here. The work to develop such systems, and conduct simulations and testing, falls on the R\&D program. Section 4 briefly describes that program, and offers desiderata for any science-driven R\&D program aimed at societal transformation.

Section 5 discusses the potential role of science and the global science community in societal transformation. Section 6 describes a theory of change by which societal transformation might be achieved. It serves as a foundation for the R\&D program. Section 7 discusses related work on reform and societal transformation. Section 8 discusses fitness metrics that could be used to assess the success of new systems. Section 9 provides conclusions, including a discussion of the limitations of this paper.

\section{The Transformative Turn}

The shift in focus from mitigation of climate change and other problems to transformation-the "transformative turn", as Dentoni calls it—is fairly new [33]. Up until the early to mid-2000s, adaptation to climate change, for example, was primarily seen as a technical and managerial challenge [3]. It is not surprising then that only limited, albeit expanding, scientific work has been undertaken thus far to clarify the aims and definitions of transformation, or the proper role of science in facilitating or fostering it [34]. Example works include [4,5,7-9,11-15,18,35-37]. Almost no work has been published in science journals discussing practical pathways through which transformation might be achieved.

Fazey et al. identify the "how to?" as arguably the most important question today for climate research [22]. They suggest that the answer must involve an expanded, explicitly normative, and reflexive second-order approach to science. A second-order science approach aims to effect change, and the scientist is understood as part of the experiment. The focus is on the process, the effort is value driven, and the participants are scientists and stakeholders who learn, develop, and evaluate solutions together.

This is in contrast to a first-order science approach, where, for example, the aim is to produce knowledge, the scientist is viewed as an observer of the system, and the research is considered value-free. According to Fazey et al., the overwhelming majority of past and current research on climate change and sustainability is based on first-order science. The proposed R\&D program represents a second-order science approach.

With regard to developing new societal systems, second-order science can be understood as "learning to learn" at the societal level and "adapting to adapt", or the "applied science of learning and adaptation". More specifically, it can be understood as a form of meta-learning in which soft and hard technologies (societal systems and associated infrastructure, rules, norms, and cultural components) are learned that themselves allow a society to excel at learning, problem-solving, and adaptation.

The need to excel at learning, problem-solving, and adaptation has never been greater. In the Anthropocene, humans are a massive and extremely powerful population that impacts all aspects of the biosphere and other Earth systems, including climate. With great power comes great danger. Unfortunately, native systems, viewed as (somewhat dysfunctional) societal cognitive architectures, appear ill-equipped to handle modern challenges. Indeed, they have allowed preventable problems to 
grow to the point of looming catastrophe. There is reason to suspect that native systems may in fact be incapable of preventing widespread catastrophe and securing sustainable vitality.

Today, societies face a host of severe, interrelated, unsolved problems, some of which act as drivers of climate change and/or biodiversity loss. These include loss and destruction of wildlife habitat; various kinds of air, land, and water pollution; topsoil erosion and degradation; depletion of groundwater and other natural resources; financial instability; poverty and other forms of income and wealth inequality; high rates of preventable disease; the proliferation of nuclear, biological, and other weapons of mass destruction; and mass migrations of refugees due to social, economic, and/or environmental stress. New problems loom on the horizon, including the misuse of biotechnology and the militarization of robotics and artificial intelligence [38]. Scientists fear that a flare-up or crisis related to any single problem could initiate a cascade of events that sets off wider and deeper damage [39].

To give some idea of the size of just the migration problem, within 50 years, in a business-as-usual climate scenario and in the absence of migration, more than three billion people (about $30 \%$ of the projected global population) are expected to experience extreme mean annual temperatures currently found only in a few isolated locations like the Sahara desert. Given the inhospitable conditions of those areas, a sizable fraction of the world population could become migrants in coming decades [40].

If native systems are incapable of successfully addressing or solving these entwined problems in a timely manner, then bold change is needed. As mentioned, this could come in the form of system reform, societal transformation, or both. Reform aims at reducing damage and improving native systems. It is, arguably, how most people conceive of bold change. Based on the literature discussed in the next section, reform could be considered a 30-year project, with a goal of achieving major progress within the first decade.

The concept of transformation is less explored, especially in the scientific literature. Transformation has to do with building fundamentally new systems. While some view transformation as being deep, rapid, and broad in scale, Termeer et al. caution that achieving all three at once is infeasible [4]. The proposed R\&D program takes a prudent, measured approach to transformation in order to keep risks low, build support, create the necessary infrastructure, conduct necessary studies, and allow for learning and adjustment at every step. As described here, transformation can be considered a 50-year project culminating in near-global-scale (i.e., widespread) change, with early adopter communities seeing benefits within a much shorter timeline.

System reform efforts are already underway by numerous groups. Transformation efforts have barely begun. Given looming dangers and a limited window of time for action, a focused transformation effort would ideally start immediately and run concurrently with reform efforts. If coordinated, the two approaches could be mutually beneficial, if not synergistic.

\section{Reform and Transformation}

The focus of reform is rapid and dramatic reductions in greenhouse gas emissions and biodiversity loss, while also reaching the United Nations Sustainable Development Goals (SDGs) [41]. Efforts by the UN, businesses, agencies, and groups have already begun. Examples outside the UN include versions of a Green New Deal, proposed in the United States and elsewhere [42-45], and the Global Deal for Nature, which addresses biodiversity loss [46].

Specific goals and targets are discussed in IPCC and IPBES reports [20,21]. For climate change, the 2050 targets include limiting warming to a threshold of $1.5^{\circ} \mathrm{C}$ and achieving net-zero carbon emissions. For biodiversity loss, goals and targets are described in the Aichi Biodiversity Targets, the 2030 Agenda for Sustainable Development (which include SDGs), and the 2050 Vision for Biodiversity $[41,47,48]$.

Reform efforts focus on and occur largely within native systems and institutions. Reform aims to limit damage, improve capacity for repair, reduce vulnerabilities, and improve conditions (for example, by eliminating the worst levels of poverty, an SDG). Societal transformation, as described here, is intended to complete the journey to system-wide reorganization. Its aim is to enable societies and 
ecologies to flourish. Compared to reform, transformation involves deeper repair and regeneration, and in the case of societal systems, fundamental reorganization.

One might question whether transformation is necessary, given the bold goals of reform. For starters, reform goals might not be achieved or might be only partially achieved. The social, political, and economic challenges are immense, and the lack of progress thus far is frightening. The 2019 twenty-fifth session of the Conference of the Parties (COP 25) UN climate conference ended largely in disappointment [49]. Greenhouse gas emissions continue to set records [50]. Summary findings in the 2019 Emissions Gap Report are bleak [51]. As of March 2020, we are still "way off track to meeting either the 1.5 or $2{ }^{\circ} \mathrm{C}$ targets that the [2016] Paris Agreement calls for", according to UN Secretary-General Antonio Guterres [52]. Likewise, of the 20 Aichi Biodiversity Targets originally defined for 2020, only four show good progress [53-55].

In addition, some current goals are set too low. The Aichi Biodiversity Target to protect $17 \%$ of terrestrial land and inland water by 2020 was set in a political, rather than scientific process, and is likely too low for safety [56]. A more scientifically justifiable target would be closer to $50 \%$, within a range of $25-75 \%$ [46].

Further, according to the IPCC report, "current nationally stated mitigation ambitions [for greenhouse gas emissions] as submitted under the Paris Agreement would not limit global warming to $1.5^{\circ} \mathrm{C}$, even if supplemented by very challenging increases in the scale and ambition of emissions reductions after 2030" [20]. Rather, ambitions are "broadly consistent with cost-effective pathways that result in global warming of about $3^{\circ} \mathrm{C}$ by 2100 , with warming continuing afterwards." It should be noted that a warming of $3{ }^{\circ} \mathrm{C}$ would put societies and ecologies far into the danger zone [57] and could lead to severe, perhaps even crippling long-term damage.

Unfortunately, we might be on track for warming beyond $3{ }^{\circ} \mathrm{C}$. Recent trends in greenhouse gas emissions most closely resemble the worst case (RCP8.5) scenario models [58]. Further, as climate models become more sophisticated, they increasingly take into account larger sets of factors. As a result, the predictions of today's models span a wider range of outcomes compared to models of the past. Some new models predict a long-term warning of more than $5{ }^{\circ} \mathrm{C}$, with the difference in predictions apparently due to how cloud feedbacks and aerosol interactions are modeled [59-61]. Warming of $5{ }^{\circ} \mathrm{C}$ would likely be catastrophic, with no guarantee that the human species would survive.

Finally, the political feasibility of taking sufficient action appears to be low. As Jewell and Cherp point out, "for key climate solutions that are already widely used, there is little evidence that they can be deployed world-wide at the scale and speed necessary for avoiding the $1.5^{\circ} \mathrm{C}_{\text {overshoot" }}$ [62]. For solutions that are still only "best practices" or demonstrations, the evidence for political feasibility is even scanter. The authors are not particularly hopeful that new public demands for action caused by increasing damage will be enough to overcome political infeasibilities and lack of capacities.

In short, societies have so far failed to stop growth in global greenhouse gas emissions and biodiversity loss, and worst-case scenarios are now looking plausible. The prospects for taking sufficient action look dim. The longer that targets are not met, even faster and deeper cuts in emissions would be required to prevent major damage. As we wait, some scientists report that the Earth's sixth mass-extinction event, the human-caused Anthropocene extinction, has already begun and is accelerating $[63,64]$.

If reform goals are not substantially achieved on time, it would mean, in effect, that native systems remain too dysfunctional to mount an adequate response to clear and present dangers. Such a failure would greatly increase the burden on transformation. A more intense effort, perhaps in a more crippled world, would be needed to repair damage and avert even greater catastrophe.

Even if reform goals are fully achieved, substantial risk will remain. For example, the $1.5^{\circ} \mathrm{C}$ threshold cannot be considered safe or damage-free [65], but rather a magnitude of warming that might limit damage to a manageable level for many, but not all, nations. Every nation, and especially poor ones, would still struggle with the impacts of climate change and perhaps also biodiversity loss in a $1.5^{\circ} \mathrm{C}$ world. Today we are well below that threshold, yet already societies struggle with increased 
intensity and frequency of climate and weather extremes, including heat waves, heavy rains, drought, wildfires, and coastal flooding [20,52].

Further, tipping points might exist in Earth systems that, if crossed, could lead to unstoppable, runaway damage $[57,66-68]$. If tipping points exist but are not likely to be reached, cutting greenhouse gas emissions to net-zero over the next 30 years might be sufficient, a goal of some reform efforts. If tipping points are likely to be reached, we may need to pull additional greenhouse gases from the atmosphere over the long term to be below net zero, and act aggressively to repair and contain damage. Both are appropriate goals for transformation.

Planned reform efforts also do not adequately address certain structural problems, including financial instability and extreme concentrations of wealth. And they do not adequately address system-engendered motivations for selfish rather than cooperative behavior. Thus, even if successful, reform efforts are likely to leave societies hampered in their capacity to learn and adapt, and with unsolved problems to address.

Given that the goal of transformation is the sustainable flourishing of human societies and their environments, one can imagine that through transformation societies will need to mount a massive, long-term repair and regeneration effort to test, clean, and restore polluted land, water, and air; reclaim deserts; plant forests and expand protected areas; stop erosion and build soil health; protect aquifers and watersheds; expand biodiversity; and otherwise heal damaged ecologies. A massive industrial retooling and reconfiguration effort will be needed to achieve effective pollution control and near-complete rates of recycling and reuse for most materials. A massive reformulation effort will be needed to remove or greatly reduce the presence of toxic chemicals in consumer and industrial products. A massive redesign effort will be needed to create products that have extended lifetimes (as opposed to planned obsolescence), and that are reusable, repairable, and recyclable. Wasteful consumerism will need to be severely curtailed. Medicine and medical research will need to shift some focus from the treatment of disease to disease prevention and promotion of health. Income and wealth disparities will have to markedly narrow. Economic and governance systems will need to become far more transparent and responsive. Energy use will need to become more efficient, and energy sources dramatically decarbonized. Individuals made homeless by social, economic, or environmental turmoil will need to be housed, fed, and integrated into new societies.

Above and beyond all this, wealthy societies will need to substantially reduce resource use per capita, even as poorer societies catch up, so that global thermodynamic and material budgets are not exceeded [23,69,70]. Among other things, this could mean adopting simpler (but not necessarily lower-quality) lifestyles for some nations. And it could mean ending continual economic growth as we know it. Some argue that degrowth is necessary $[17,18]$. New and better indexes of societal health and wellbeing will need to be developed and implemented, replacing gross domestic product and related indexes as primary indicators.

In short, the need for repair, regeneration, retooling, reconfiguration, reformulation, and redesign, even reduction and simplification, across all sectors of business, civic life, and government amounts to a sea change in human endeavor. It is almost inconceivable that such a shift-much of it aimed directly at improving the common good, much of it highly disruptive to existing industries and business models, much of it incongruent with existing economic and financial systems-could occur without transformation.

Whatever the success of reform, we can expect that major problems, if not crises, will remain. Societies worldwide will continue to face enormous strain and challenges. Transformation is needed to empower societies, as much as possible, to rise to challenges, to expand opportunities, to learn and adapt, and to solve those problems that must be solved.

\section{R\&D Program}

Before describing the proposed R\&D program, it is useful to consider for comparison reasonable desiderata for any science-driven $R \& D$ program that is aimed at societal transformation, understood as the de novo development of and migration to new societal systems. Desirable characteristics include: 
1. It describes the goals and scale of intended transformation, along with costs, risks, and an approximate timeline in which goals will be achieved.

2. It is based on second-order science, which means in part that:

(a) it aims to promote and instigate societal change, not just study it as an observer

(b) it represents a partnership between the scientific community and the interested public

3. It defines a theory of change by which goals might be achieved. The associated strategy for change is politically, socially, and financially viable, meaning that the goals of the program could reasonably be achieved in the provided timeline, given the world as it exists.

4. It does not require that individuals act in opposition to human nature in order to achieve program success. For example, it does not expect individuals to be overly altruistic. Rather, it takes human nature, including needs, motivations, desires, and variability, fully into account. Further, it describes how system design is intended to impact motivations for prosocial versus antisocial behavior.

5. It develops new, integrated systems that span all six overarching categories, summarized here as economic, governance, legal, health, analytical, and education systems.

6. It describes the purpose of societal systems, such that the quality of designs might be assessed. Related, it describes the metrics and means by which the fitness and function of alternative designs might be assessed and compared.

7. It discusses the impacts of system design on societal cognition, and the roles of information, computation, transparency, and forecasting

8. It develops flexible options that the public can choose from, rather than one-size-fits-all solutions.

9. It describes an ongoing, iterative process by which new system designs might be developed, tested, implemented, monitored, and improved.

10. It makes its work freely available to the public via publication of data and findings, as well as through open-source or related licenses for intellectual property. In particular, the technology it develops is not proprietary, thereby allowing the public to freely access, use, and alter that technology.

11. It addresses the cultural changes necessary for transformation, and how these might be brought about (for example, via education, discussion, outreach, training, etc.). In particular, it addresses the education and training needed to successfully operate new system designs.

12. If new systems are to be implemented in multiple locations (for example, in multiple communities), it describes whether and how these implementations are intended to communicate and cooperate with one another.

13. It develops systems that are fair and just and that can be widely implemented. In particular, designs do not favor a limited few, precluding others, internal or external, from realistically achieving similar benefits.

14. It addresses the expected impacts of new systems on the environment and natural resources, as well as on native systems and their participants.

The R\&D program discussed in this paper and series is conceptual. It is a program that could be funded, administered, and otherwise actualized. The series does not constitute a formal proposal, but rather provides a foundation that addresses each of the fourteen desiderata, at least briefly. Several are discussed in this section.

The aims of the R\&D program are to research, develop, test, implement, monitor, improve, and advocate for new societal system designs that can best improve the common good. In [24] these are called societal active inference and learning systems (SAILS), emphasizing their cognitive aspects. Common good here means the degree of current and expected thriving (i.e., vitality, flourishing), broadly defined to include factors of social and environmental wellbeing, uncertainty reduction, sustainability, resilience, robustness, and problem-solving capacity. 
Ultimately, thriving is a functionality that has two aspects. Proximally, it is the capacity to sense, learn, decide, communicate, and orchestrate cooperative action. That is, it is society's cognitive (action-inference) capacity, related to the design and mechanics of its societal systems. The distal aspect is the conditions that arise from, or the effects of, societal cognition. Examples include the current and expected degree of security, public health, and environmental quality. The distinction between proximal and distal aspects of thriving suggest design elements and sets of fitness metrics by which system quality and operations might be assessed.

As envisioned, the R\&D program occurs over an approximate 50-year horizon, with the first 10 years focused on capacity building, foundational studies, and development and testing of initial system designs. In concept, a given design or design idea first undergoes and is iteratively improved through a series of preliminary studies that could include computer simulations and various kinds of laboratory and group testing. If preliminary studies are successful, the design could progress to the field trial stage. Here, a fully functional system would be tested in partnership with a small, volunteer community. As will be discussed in Section 6, Theory of Change, a community implements a new design via a special kind of civic club. The new system acts as an overlay to native systems.

Over time, the program evaluates numerous designs and design elements, each of which could be tailored to the particular needs and desires of a community. Core elements of intellectual property developed by the program are made available to the public through open-source or similar licenses.

The program begins as soon as funding is secured and adjusts over time, as necessary, to the successes and failures of reform efforts. As will be discussed in Section 6, some focus eventually shifts from the design of systems that are implemented by clubs to the design and testing of club networks, which connect and support clubs and which are also viewed as cognitive architectures.

The R\&D program seeks to address a wide range of basic and applied science questions related to societal transformation, thriving, and system design and operation, using a variety of tools and approaches that include simulations, modeling, theory development, laboratory studies, population studies, and user testing. Over the course of the 50-year program, perhaps thousands of science papers would be published. Program efforts touch on nearly all scientific fields. To give a flavor, topics eventually span agriculture, agroforestry, arts, climate and Earth systems science, cognitive science, complex systems science, computer science, ecology and environmental sciences, economics, education, ethics, evolutionary biology, information theory, law, linguistics, literature, materials science, media, medicine, philosophy, physics, political science, psychology, public health, sociology, statistics, and zoology—literally an A-Z of academic fields, reflecting the broad goal of transformation and the high complexity of nature and society.

For convenience, I refer to the program as being science-driven and led by the scientific community. However, obviously it involves many fields and topics beyond basic or applied science. Further, consistent with a second-order science approach, it consists of a partnership between the scientific community, local communities, and other elements of the interested public. As such, the scientific community can be more accurately viewed as a co-leader.

The program involves the public in a variety of ways, one of which is field trials. The public can participate in all phases of design, development, and testing, as well as in the monitoring, improvement, and continued study of systems after field trials are completed. The public can also help facilitate the growth and replication of implemented systems. The program includes cultural and education projects that involve the public. For example, it hosts classes, discussions, and outreach, as well as music, literature, media, and other arts projects.

The R\&D program consists of a core administrative group and a small to large set of researchers, program managers, and other staff. It engages the global scientific community in a number of ways. If adequately supported, it could disperse funds to high-quality proposed projects and otherwise serve as an organizer of efforts and information. It could also act as an advocate for projects that seek funding from other sources. It might be centered within one or a few academic institutions, or within a 
new or existing civil society organization. The program could develop a consulting arm, or partner with a consulting organization, in order to provide services to communities.

The conceived R\&D program is but one possible means to achieve societal transformation. Other kinds of R\&D programs, involving other approaches, worldviews, and/or theories of change are possible. To compare and contrast programs, it might be helpful if new proposals address the fourteen desiderata considered here. Although some related work on reform and transformation is discussed in Section 7, by and large, this is the first R\&D proposal of its kind in the scientific literature. As such, it is not yet possible to contrast it directly with other proposals or programs.

\section{Role of the Scientific Community}

The need for, meaning of, and paths to transformation are still unsettled in the scientific literature, as is the proper role of science in fostering transformation. While few papers to date have addressed these topics, one might expect interest and the number of papers to grow exponentially fast, especially as (or if) conditions deteriorate. With a view to the proposed R\&D program, there are several reasons why it is appropriate that the scientific community adopt an early leadership role in systems design and societal transformation:

- Societal cognition, via societal systems understood as a cognitive architecture, is a timely and important subject that could advance scientific knowledge in multiple fields.

- Systems are sophisticated and include social, economic, environmental, and technological aspects. They must reliably and securely operate under various kinds of stresses and shocks, even rare ones. System design will require simulations, field trials, and other types of studies, as well as innovations in communications, data science, and other fields. A large set of computational models will be needed for both system testing and daily operations of new systems. Metrics and tools must be developed for assessing and monitoring system fitness and social and environmental conditions. The scientific community is uniquely qualified to contribute to these efforts.

- The goals of transformation are ambitious, yet the time available for action is short. Substantial progress must be achieved in just several decades. There is little room for casual trial and error. Mistakes, while unavoidable, must be minimized. Time and resources must be efficiently used. The scientific community can help keep the effort focused, on track, and grounded in scientific methods.

- By stepping across the second-order threshold in system design, the scientific community gains the opportunity to play a more pronounced and profound role in guiding the intentional evolution of societies toward more optimal futures.

- The scientific community is trusted by the global public and is therefore in a position to help focus public attention on pressing problems, viable solutions, and possible positive futures. Further, the science community has fewer vested interests in the outcome of systems design compared to other institutions or groups of native systems. It is positioned to be a trusted authority on the development of new designs. As a side benefit of trust, an honest effort toward transformation could inspire hope in a population, and hope by itself could reduce the spread of violence and despair as (or if) conditions worsen.

- The scientific community can offer a global perspective, and global coordination. As one example, Earth systems science necessarily looks at the big picture. A global perspective can help inform, unify, and guide local efforts. Further, the scientific community can offer a consistent foundation that not only survives over time but that continues to learn, even if some individual projects at the local level are unsuccessful.

- The scientific community can serve as a powerful ally to the public in promoting and securing transformation. Apart from technical skills, the scientific community can to some degree positively influence discussions and narratives within boardrooms, governments, media, and elsewhere. 
If the scientific community fails to adopt a leadership role, the prospect for humanity to achieve a bright collective future is less certain. In a leadership vacuum, and under growing social and environmental stress, who or what would take the place of science?

\section{Theory of Change}

A theory of change is one item in the desiderata listed in Section 4. An R\&D program aimed at societal transformation would not be very useful or complete if it did not present a viable strategy by which its goals might be achieved.

The proposed R\&D program employs a novel local-global hybrid strategy called transform local, engage global, spread viral, or local-global-viral, for short. Local refers to a local community that implements a SAILS via a civic club model. A club constitutes a SAILS and consists of a group of people and local organizations that voluntarily choose to participate. Clubs act as a new layer of self-organization on top of native systems, complementing and competing with them. Club members remain engaged with the wider community and continue to participate in native systems. The local-global aspect refers to a partnership between clubs and the global scientific community, the latter of which develops the technology and infrastructure necessary for SAILS, conducts monitoring and assessment, and performs other tasks. The viral aspect refers to the growth of local clubs and the replication of clubs to new areas. The local-global-viral strategy allows even a small community to implement a full suite of quality systems.

While the initial focus of the R\&D program is on club design, over time focus will expand to include the designs of club networks, which connect clubs, facilitate cooperation, and assist the viral replication of clubs. The combination of clubs and networks, by design, allows for exponential growth in total membership, such that organic transformation on a near-global scale is possible within a reasonable span of time.

\subsection{Clubs and Club Networks}

Clubs and club networks represent a type of hybrid, soft and hard, innovative technology. Soft refers to elements like theories, social norms, goals, rules, procedures, programs, and stated purpose. Hard refers to technological elements like hardware, software, and methods for communication, data representations, data storage, and computation, including models for forecasting. Given that the strategy involves viral spread, the uptake of club technology in the general population is of central importance. In keeping with research on innovation diffusion [71,72], clubs are designed so that the barriers to participation are low and the benefits of participation are high. In overview, new systems are designed to outcompete native ones for the public's attention, engagement, trust, and respect. The theory of change is one of viral spread and voluntary shift to new systems.

A club represents the Goldilocks level for testing and implementing new system designs; it is neither too small nor too big. If clubs were smaller, say, representing one business, they would have too little impact on society and would be too fragile. Their vitality would heavily depend on native systems, like financial systems, which are outside of their control. If clubs were larger, say, representing a large city, they would be too costly to study and implement, and the shift to new systems would be politically unviable. In the hierarchy of business, club, city, region, and nation, a club is the smallest level of organization that allows a SAILS to be viable, testable, self-replicating, and effective. A new club can be started by just a small number of interested people, businesses, and groups, on the order of 1000 individuals. Further, in most locations, a club can be started without legislative action, which greatly reduces political obstacles.

By design, participation rates are expected to grow high over time, perhaps even to approach $100 \%$ in some local populations. Conceivably, a city could formally adopt a club model. However, there is likely a size limit beyond which clubs become less effective and responsive. Research on this topic is needed, but as conjecture, perhaps the threshold is near one million participants. If so, it would 
mean that some large cities spawn multiple, interacting clubs. Related to this, designs could allow for individuals to participate in more than one club at a time.

Thus, the systems-economic, governance, legal, health, analytical, and education-of direct concern in the R\&D program are the SAILS embodied by clubs and club networks, not native systems. In practice, however, participants naturally engage with native systems. As such, club participants would naturally influence the operations and evolution of native systems. Further, the influence of clubs on native systems would likely grow as clubs grow and spread. For example, clubs might bring public attention to certain issues and causes.

While the focus of the R\&D program is on SAILS, the endgame vision is that a high percentage of the global population uses societal systems that excel at serving the common good. This vision could be realized through a number of different scenarios. For example, clubs might grow successful and popular enough that, largely through example and leadership, they transform native systems from the inside out. In this scenario, clubs demonstrate what is useful, desirable, and possible. Native systems adapt and evolve to incorporate the most beneficial and critical aspects of clubs.

Another scenario is that native systems do not adapt and improve enough to outcompete clubs for the public's attention, engagement, trust, and respect. Doing so would be a challenge for native systems, as clubs are specifically designed to attain these. Clubs offer something that individuals deeply desire: the power to collectively and effectively learn, decide, adapt, and cooperate in problem-solving, and therefore also the ability to reduce uncertainty and improve vitality. In this scenario, participation rates grow very high over time, clubs spread widely, and power (and legitimacy) naturally shift toward clubs and club networks. Native systems, in turn, are rendered less relevant and potent.

In both scenarios, and in others that could be imagined, the program achieves its endgame vision.

\subsection{Club Growth and Replication}

As mentioned, clubs and club networks represent a type of technological innovation, and the uptake of innovation by the public is more likely if the barriers to participation are low and rewards are high. According to Rogers, five characteristics influence diffusion and uptake: relative advantage, compatibility, complexity, trialability, and observability [73,74]. Each can be considered in club design, as can other ideas from the diffusion literature.

Rogers also classifies individuals into five adopter categories: innovators, early adopters, early majority, late majority, and laggards. Considered as generic classes, innovators and early adopters would be the initial targets of the R\&D program. The percentage of innovators and early adopters in a given location, or on average across locations, that might be interested in participating in a club is still unknown. It remains a topic for future research. However, given that a club can form with only a small number of people (roughly, 1000), and given that only one club in one location in the world is necessary in order to hold the first field trial, it seems likely that recruiting enough people for that trial will not present a major obstacle. If the first field trial indicates that a club offers substantial benefits to members, then recruiting individuals and organizations for subsequent clubs and field trials should be easier. Over time, educational materials developed by the R\&D program, outreach efforts, and published results (on laboratory and population studies, field trials, etc.), will likely affect the level of interest that individuals have in club participation.

Design work and preliminary studies could occur over several years or longer before the first field trial is ready to start. Results from simulations and other types of models should be available at the start of the first trial, and participants should have a very good idea of how the new system is supposed to function, how conditions are likely to change from year to year, and the benefits, costs, and risks that participation is likely to bring. If the preliminary work is thorough, there should be very few surprises in the outcomes of a trial. This is not to imply that a system is deterministic. Rather, it is driven by the daily choices of participants. While the general trajectory is a part of system design (a system is designed to achieve requirements), participants can steer their system as they see fit, altering course as necessary in response to local conditions. 
A field trial is likely to occur in a phased fashion. Conceptually, the first two years would be most intense with regards to data collection, assessment, and interactions between the community and the R\&D program. It should be possible to limit the financial risk of participants during this period via a bond or other mechanism that allows for the recovery of financial loss if a trial goes badly. At the end of the first phase, a community could decide if it wishes to continue using the system. If the answer is affirmative, then several more two-year phases could occur, with the R\&D program playing a reduced role in each.

Once the initial phases of the first few field trials are complete, and assuming that systems perform as designed, a growing set of communities will likely show interest in the next round of trials. At some point, even while trials continue, other communities will begin to implement systems outside of the field trial format. Meanwhile, aided by the R\&D program, networks will form to connect clubs and promote cooperation. At that point, the conditions for exponential growth will be achieved-clubs and networks will be capable of "going viral." This is consistent with viral growth and spread in biology and ecology. Of course, no population grows or spreads exponentially fast forever. Clubs and networks will reach a saturation point, and growth and replication will eventually slow down. At that point, networks may have spread through much of the globe. Further, as clubs replicate and networks form, networks themselves might organize to form networks, which could organize to form larger networks still, and so on, with each new layer representing a more global perspective. This is not unlike the way the human brain and other natural systems have organized over time, as discussed in [24].

Clubs are interdependent and the actions of one affects others. As such, they cannot act without restriction. Internally, and externally due to networks, each club is motivated to act responsibly, according to common goals and values. If it does not, its vitality suffers and it risks alienation from other clubs. The result could be a loss of support and cooperation, and perhaps other collective actions as allowed by network rules and under existing laws. Clubs and networks can be designed to encourage responsible action, as well as cooperation in such matters as trade, business formation, club replication, education, healthcare, cultural exchange, training, and environmental restoration.

\subsection{Strategic Advantages}

Consistent with low barriers to participation and high rewards, there are several advantages to the local-global-viral strategy compared with other possibilities. First, it achieves change via a nonviolent, constructive process, which means it does not harm others or exist as an anti-movement. Rather, it acts to secure elevated wellbeing for participants and also for the wider society and environment. Further, it measures status and progress through scientific, rational, and verifiable means.

Second, the strategy minimizes political opposition. In most democratic nations, individuals can start or join a civic club without any preauthorization or legislative action. Thus, there are few if any voting hurdles that must be crossed in order to start a club, which means that there is no need to convince a larger public body that transformation is necessary or that the club approach is useful. Moreover, the presence of a successful club in a city is likely to produce beneficial spillover effects for the city as a whole. As such, a club might be welcomed and valued by many residents of a city. Benefits could include a stronger and more stable local economy; higher tax revenues for local governments; improvements to parks, roads, and other public infrastructure paid for in whole or in part by clubs; a stronger manufacturing base; increased tourism; and increased social, education, cultural, and professional opportunities. Such benefits could breathe new life into some rural areas, including cities that have been aging and losing population for decades or that struggle to maintain quality of life.

Third, the local-global-viral strategy is less costly, less risky, and more flexible than other options. Implementing a local club would be far less expensive, easier, and safer than implementing a new societal system at the regional, national, or global scale. The strategy allows clubs and networks to start small and grow organically over time. Further, it allows for parallel testing of different system 
designs and design components in a wide range of environments and conditions. By starting small, growing organically, and testing in parallel, improvements can be made and bugs worked out without undue risk to large populations.

None of this is to suggest, however, that the growth and replication of clubs would be unacceptably slow. While the viral strategy starts slow and clubs start small, exponential growth allows total participation to reach a near-global scale within several decades (recall the 50-year horizon). Benefits to local populations, global society, and environments expand exponentially fast. Early adopters see benefits relatively quickly.

Finally, the cost of the program is small both in absolute terms and as compared to potential benefits. Costs are certainly far lower than other bold scientific endeavors, such as space exploration or the Large Hadron Collider. Yet potential benefits are similarly massive. Adequate progress could be made at a level of funding typical for a large technology startup. Roughly, annual costs in the first year or two might be less than $\$ 10$ million. Annual costs in subsequent years, still within the first decade, might be on the order of tens of millions of dollars.

\subsection{Opportunities}

Beyond the advantages mentioned, the strategy offers opportunities for some forward-thinking businesses to play an important role in the larger transformative turn. The task of developing and testing the software, hardware, and other technological infrastructure for SAILS falls on the global scientific community. Some portion of the R\&D effort could occur through one or more businesses that operate similar to RedHat Inc., which provides consulting, training, and other forms of assistance to groups that use the Linux open-source operating system. Like RedHat, companies could support R\&D; offer services and products that sit on top of and improve the open-source stack; and provide training, consulting, and other services to clubs. Given the need for transformation, and the common desire for increased security and greater thriving, companies acting in this space could potentially grow to a size that rivals RedHat, now a billion-dollar publicly traded entity.

Future conditions could expand the market even further. For example, mass migrations of environmental refugees are expected as conditions worsen, as noted. Patterns of population density are likely to shift [75], and whole new communities and cities could spring up. All present opportunities for the club model. Further, patterns of population density could shift if smaller thriving communities using the club model become established beyond what are now large metropolitan areas. The decades-long trend toward urban growth could slow or even reverse if equal or better opportunities and a higher quality of life exist elsewhere. To some degree, this might already be happening in response to Covid-19; as employers shift to offering remote and flexible work options, employees have new flexibility in choosing where they will live [76].

Clubs sit midway between the business and city levels of societal organization. Markets for business and city are currently massive, but the middle ground is not yet organized. When it does organize, it could rival the others in size. One might expect that it will organize because this is the ideal level for empowering local communities that are subsets of a city. It is also in keeping with how complex systems naturally self-organize. Power is distributed in successful systems, hierarchies form across levels, and the smaller, local organizations tend to be more informed about, and responsive to, local needs.

There are hints that the middle ground is already starting to solidify. For example, neighborhoods are starting to act as their own generators of electric power via microgrids [77]. NextDoor, a private social network tailored to the neighborhood level, has grown popular and is now valued at more than $\$ 2$ billion [78,79]. Further, numerous groups in the United States, United Kingdom, and elsewhere have started community currency programs [80,81]. Eventually, clubs themselves could cooperate in spawning service companies to act in the club/middle-ground market.

Two other opportunities are worth noting. First, local governments might greatly benefit from the presence of a club. In particular, tax revenues could substantially increase. A simulation of an idealized, 
prototype club model (discussed in [25]) illustrates how the average family income of members rises (more than doubles) over a period of years, in concert with a fall in the local unemployment rate. The simulation is for a modest size club of about 100,000 members at maturity. Even at this size, its members and member businesses generate more than $\$ 1$ billion in tax revenues, which is more than double the initial tax revenues. A club is also likely to improve quality of life for the surrounding community, as it seeks to improve its own quality of life. For example, a club might help fund parks and other community projects. Thus, it is not unreasonable that a consortium of city and county governments could eventually form to participate in and assist with the R\&D project.

The second opportunity is for institutional and other large investors. Assets held by the 300 largest pension funds fell by $\$ 81$ billion (0.4\%) globally in 2018 [82]. Losses could mount in the future, considering that the trend is toward greater social, economic, and environmental strain due to climate change, biodiversity loss, and other unsolved problems. In December 2019, the Bank of England governor, Mark Carney, warned that pension funds are at risk due to climate change, cautioning that some assets could become worthless [83]. If conditions worsen over the coming years, clubs could come to represent a safe haven for long-term social investments. Large investors might become interested in reasonably safe but low- or zero-yield long-term social investments, faced with potentially worse outcomes. Moreover, public pressure is growing on large investors to shift funds in order to address climate change and other pressing problems [84].

\section{Related Work}

Over the last several decades a substantial effort has been made by some government agencies, nonprofits, corporations, universities, industry groups, policy-makers, and others to address climate change, biodiversity loss, and other social, economic, and environmental problems. Some were mentioned in the first section of this paper, categorized as reform efforts.

Aspects of some reform efforts relate to the R\&D program. One example is smart city programs, which typically seek to increase energy efficiency and reduce the ecological footprints of cities. Some smart city programs also address the quality of life for city residents. A variety of ideas explored in smart city programs, such as energy efficiency, energy generation, and communication of resource status and flows, could be incorporated into club design and operations.

Numerous other projects seek to improve wellbeing, improve decision making, and/or deepen democracy. Examples include programs that encourage ranked voting in elections [85], and programs like Evergreen Cooperatives that fund and support local cooperative businesses [86]. Programs like Liquid Democracy (and the software tool LiquidFeedback) represent new approaches to democratic voting, including online and delegated voting $[87,88]$. Tools like Loomio facilitate online collaboration and decision making [89]. Basic income programs aim at increasing income security by providing a stipend to all citizens of a region, regardless of need [90].

Finally, numerous community currency programs exist, and in some cases are backed by cities. An example in the UK is the Bristol Pound [91]. It and many others use Cyclos, an advanced open-source payment system [92]. Related are Community Inclusion Currencies (CICs). One, in Kenya, is sponsored in part by the Red Cross with modeling work done by Grassroots Economics [93-95]. The International Journal of Community Currency Research publishes reports and developments in the community currency field [96]. Socially responsible global digital currency systems are also starting up, an example being SEEDS [97].

Although a club design might employ a community currency system, support cooperative business models, and use new online tools to improve democratic voting and decision making, the proposed R\&D program is wider in scope and ambition compared to the projects just mentioned. For example, basic income programs do not design new systems (e.g., new economic systems). Rather, they help individuals to function within existing systems. As an aside, the amount of money basic income programs disperse to individuals might also be smaller than that offered by clubs. The typical stipend in a basic income program is about $\$ 1000$ per month per adult. A simulation model of 
an idealized, prototype club system (see [25]) illustrates how incomes rise and equalize over time, eventually reaching the equivalent of about $\$ 110,000$ for all families who join the club [32], regardless of work status. This is roughly 4.5 times higher than a typical basic income stipend.

The goal of the proposed $R \& D$ program is a science-driven societal transformation on a near global scale. It addresses all fourteen desiderata listed in Section 4. As such, it necessarily involves a large, integrated, and advanced set of tools, technologies, and methods, and has the potential to impact a wide sphere of societal activity. In contrast, other projects discussed in this section are smaller, have more limited goals, and/or are not science-driven R\&D programs. Nevertheless, it is reasonable to ask if these might be sufficient to reach the goal of transformation. If so, perhaps the R\&D program is not necessary.

It seems unlikely that smaller or more narrowly focused projects could achieve widespread transformation within a reasonable length of time. First, most do not hold widespread societal transformation as a goal.

Second, even for the proposed program - a focused and hopefully well-funded R\&D effort that engages the global scientific community-transformation at a near-global scale is cast as a 50-year project. It stands to reason that smaller or more narrowly focused efforts would take longer.

Third, projects that are not science-driven or do not strongly engage the scientific community might produce system designs that are less effective, robust, or resilient. Rigorously assessing these qualities requires considerable expertise. Even when grassroots-grown systems dramatically boom, they can also dramatically bust, as happened in the early 2000s with the Trueque, a community currency system in Argentina [98]. Better design and more thorough testing might have helped to prevent its fall.

Fourth, an integrated approach is necessary, in that the six overarching categories of systems are deeply entwined. It would be difficult to make progress in one without making progress in others, and having their support. A financial system is needed for job creation, for example, and a governance system is needed to steer job creation, as well as to steer the operation of financial and economic systems. System components developed and implemented as separate, standalone entities would be at a disadvantage. For example, a community currency system that does not also have an adequate governance system to manage it, or an associated market and economic system to foster the circulation of new currency, or a financial system to focus currency flows toward useful projects, is unlikely to expand to its full potential. Likewise, cooperative businesses are unlikely to reach their full potential if they do not operate within economic and financial systems designed to support cooperatives.

A number of groups and programs deserve special mention as working on themes that are complementary to the R\&D program. These include Transition Towns [28], New Economy Coalition [99], Peer2Peer Foundation [27], Economy for the Common Good [100], Next System Project [101], Sustainable Economies Law Center [102], and Wellbeing Economy Alliance [103]. Of note is Participatory Economics, which proposes a model for a new economy [104]. Unlike the current proposal, its focus is limited to economic systems and it is not described as a science-driven R\&D program.

On the academic/research/institute side are Center for the Understanding of Sustainable Prosperity (CUSP) [26]; Stockholm Resilience Centre [105]; Great Transition Initiative [106]; Research and Degrowth [107]; Sustainability Transitions Research Network [108], with a focus on the meso-level of societal organization (and which tends to view capitalism as a landscape factor beyond the meso-level [36]); and the Santa Fe Institute [109] and New England Complex Systems Institute [110], with a focus on complex adaptive systems. See also the work cited in [37].

The R\&D program would seek to engage these and other groups.

\section{Fitness Metrics and Indexes}

As discussed in [24], fitness metrics are positioned as a precursor to system design to suggest a kind of reverse engineering process. We might wish for certain target levels of social and 
environmental wellbeing, for example, or for enhanced societal cognition. What kinds of designs would help us reach those targets within a reasonable length of time? In preparation for the third paper in the series, which is focused on design, and to address items in the desiderata, this paper ends with a brief discussion on fitness metrics and how they might be used.

An organism (or superorganism, such as a society) senses, learns, and acts in order to achieve and maintain vitality. To do this, it must monitor its own status, including the status of its cognitive facilities. Recall from [24] that an organism is fundamentally anticipatory, and prediction requires information. A club must monitor its current status in order to determine its level of vitality and to anticipate the trajectory of that vitality.

As discussed in [24], the objectively important variables that deserve monitoring are those that reflect the physiological and psychological needs of members. As per extended self-identity, they also reflect the needs of environments and ecologies. Together, these variables are called essential variables. Consistent with active inference, the cognitive actions of a club largely revolve around reducing expected uncertainty about essential variables.

The true essential variables, which completely and accurately capture the status of a club with respect to vitality and its trajectory, are unknown and unknowable. They are hidden, in the mathematical sense. Any large set of real-world variables is likely to represent a smaller, unknown set of hidden variables. Although hidden, they can be estimated, perhaps as a condensed linear or nonlinear combination (via dimension reduction) of the larger set. For example, a maximum entropy network approach has been used to assess the inter-relatedness among a large set of health-related variables for cities [111]. The result, in this case, is a single (one-dimensional) integrated health indicator.

Hereafter, the term fitness metric refers to a variable (e.g., family income), measured in a standardized way, that contributes to the estimation of essential variables. Fitness indexes are estimated essential variables, or intermediate approximations of them, derived from a larger set of fitness metrics.

\subsection{Purpose of Fitness Metrics and Indexes}

Fitness metrics and indexes serve several purposes in the R\&D program and in club design and operation:

Assessing status. Fitness metrics are the information that a community has about itself. Indexes are a summary of that information. They span a wide range of topics that could include health, trade, economics, education, skills, ecosystem diversity, pollution, recycling, soil quality, water quality, property use and ownership, demographics, leisure time, parks, traffic, funding, employment, food production, waste production, manufacturing, supply chain use, currency flows, energy use, income, and wealth. A community should have enough information about its needs, actions, desires, conditions, concerns, and impacts, both past and present, to understand itself. Monitoring and reporting are a part of assessing status.

Forecasting. Prediction is a core aspect of cognition. Fitness metrics and indexes are the data on which forecasts of future conditions are based. Predictive accuracy itself, in its various forms, could constitute a set of fitness metrics. Predictive accuracy can pertain to formal mathematical models, as well as to informal and semi-formal predictions made by individuals and groups. Some people and groups are particularly good at foresight, and their capability can be recognized. Problem-solving. Humans, and increasingly, machines (e.g., artificial intelligence), can excel at problem-solving. For example, people can identify a path of action to reduce risk and achieve a goal (clean water, for example). Problem-solving for humans and machines depends on conceptions, or models, of the world. These, in turn, depend on information/data, which metrics and indexes can provide.

Assessing system design. Fitness metrics are used to assess the ex ante and ex post fitness of system designs. To some degree, this occurs at the club level, where a community might continuously monitor its own system to identify weaknesses, strengths, risks, and opportunities for improvement. 
It also occurs at the network and especially R\&D program levels. Two of the program's central tasks are to assess and compare designs. Such assessments require data.

Informing members. Fitness metrics and indexes represent rich information that club members could use in their day-to-day activities. For example, a business might desire timely information about supply chains, product or materials demand, or community conditions. A person might desire timely information about pollution or food quality or availability. Thus, a club not only collects and processes information, creating indexes and forecasts, it also presents and disseminates the results in a way that is useful to members. To these ends, a club would likely operate or participate in a secure, intelligent data repository.

Basic and applied science. The rich information that clubs collect would be a boon to medicine, public health, sociology, environmental sciences, complex system science, and numerous other fields. For example, a club might collect information about the health of members, or product safety and disposal. This information could lead to improved, longer-lasting, and/or safer products and therapies. From a science standpoint, a large repository that contains longitudinal records of individuals on diverse topics would be a gold mine. It could accelerate the rate of scientific discovery.

Generally speaking, predictive models can be used in two ways (or two different kinds of predictive models can be created). In the forward direction, the input is a set of past and current conditions and the output is a forecast of future conditions. In the backward direction, the input is a set of targets that a club would like to achieve. The output is a path or policy that leads from current conditions to the desired future, as just discussed for problem-solving. Such models could be applied to club design itself. Computational power will increase in the coming decades, and as it does, clubs will increasingly be able to choose desired social and environmental goals and then let models work backward to suggest not just optimal paths of action, but optimal system designs and alterations that can best achieve those goals.

\subsection{Relation to Census Data and SDGs}

Two existing programs that also focus on data collection are worth noting, to contrast them with data collection in clubs. These are national census programs and the UN Sustainable Development Goals [41]. The similarity with clubs is that the information collected spans a wide range of social and environmental topics [112]. The differences are that a larger and more detailed set of information is collected by clubs; information is collected and managed at the community level (rather than national levels); information is about local conditions (rather than national conditions); forecasting and other kinds of models are integrated into the information system of a club; and the data repository, fitness metrics, and information processing system for clubs is designed to serve a different set of purposes, related to club cognition.

Lastly, a club collects information on a far more frequent basis. Nations submit SDG reports annually, as do some census programs. Other census programs collect information at two, five, or ten-year intervals. In contrast, some information for clubs would be collected almost continuously, while other information might be collected on an hourly, daily, weekly, or different schedule. Connected sensors and other Internet of Things devices can play a role here. A community makes decisions every hour of every day and needs timely and accurate information with which to do so. At every point in time, a community should have a good understanding of how it is doing, where it is headed, where it came from, and what is likely to happen next.

\section{Conclusions}

The idea that societies must undergo bold change is gaining ground. Two complementary, if not synergistic pathways to bold change are reform and transformation. Both may be necessary if humanity is to sustainably thrive over the long term. Transformation is a slower process than 
reform, but the results are deeper and longer-lasting. There appears to be a public interest in transformation, as evidenced by groups such as Transition Towns, New Economy Coalition, Peer2Peer Foundation, Economy for the Common Good, Next System Project, and Wellbeing Economy Alliance. Some religious leaders, including Pope Francis, are adopting the language of transformation [113]. Thus, there is reason to believe that enough public support is or would be available to initiate the proposed R\&D program and, eventually, to conduct the first field trial. Likewise, as evidenced by tens of thousands of signatories to the warning letters of Ripple et al. [1,2], and by groups such as Great Transition Initiative [106] and Sustainability Transitions Research Network [108], there is reason to believe that enough interest in transformation exists within the global scientific community that, with adequate funding, work on the R\&D program could move forward.

Securing funding for the program is a challenge, but one that should not be insurmountable. Program costs are moderate in absolute terms, not unlike costs for larger technology startups, and tiny compared to potentially massive benefits. Once funding is secured, the program can move forward. As it picks up steam, and especially as field trials begin, successes should lead to greater public interest and easier access to funding.

Other challenges exist. Substantial effort will be required to address a host of technological and social issues. But these do not constitute roadblocks. Indeed, the political and financial hurdles to transformation might be modest compared to those of reform. By design, the local-global-viral strategy minimizes obstacles to the testing, implementation, and spread of new systems. Compared to reform, transformation does not necessarily involve native systems and institutions, and so does not require them to vote, act, approve, or change their behavior. Electoral victories are not required. Nor does transformation require the mobilization of trillions of dollars within native systems, as does reform. Once new systems are established, however, raising large sums within clubs and networks for worthwhile projects should be relatively straightforward.

Regardless of comparative ease, both reform and transformation appear necessary, and as mentioned, could be synergistic.

This paper provides a narrative in support of the thesis that societal transformation is prudent, attractive, and achievable. As part of this, it describes the foundations for an R\&D program aimed at societal transformation. This is a concept paper, however, not a research paper or rigorous literature review. Alone, this paper and the series are not sufficient to convincingly demonstrate that transformation is prudent, attractive, or achievable, or that the proposed R\&D program is sound. Evidence is needed for that. Generating evidence is a responsibility of the R\&D program, and answers to some questions will need to await program formation. That is, to know with some certainty what is possible, we will have to try. But some studies could be conducted, short of establishing a formal R\&D program, that could generate helpful information. As one example, attitudes of the public and scientific community toward the kind of societal transformation discussed here could be examined.

Hopefully, this paper and the series can serve as a pointer toward useful directions for future research and serve to launch deeper and wider discussions about transformation, especially the "how to?" of transformation. Those discussions, in turn, could help to improve and refine the concepts presented here. They could also lead to new proposals for R\&D programs that work along different lines.

Funding: This research received no external funding.

Acknowledgments: I would like to thank Ning Yan for reading the manuscript and offering helpful comments and suggestions.

Conflicts of Interest: The author declares no conflict of interest.

\section{References}

1. Ripple, W.J.; Wolf, C.; Newsome, T.M.; Galetti, M.; Alamgir, M.; Crist, E.; Mahmoud, M.I.; Laurance, W.F. World Scientists' Warning to Humanity: A Second Notice. BioScience 2017, 67, 1026-1028. [CrossRef] 
2. Ripple, W.J.; Wolf, C.; Newsome, T.M.; Barnard, P.; Moomaw, W.R. World Scientists' Warning of a Climate Emergency. BioScience 2020, 70, 8-12. [CrossRef]

3. Godfrey-Wood, R.; Naess, L.O. Adapting to Climate Change: Transforming Development? IDS Bull. 2016, 47. [CrossRef]

4. Termeer, C.J.A.M.; Dewulf, A.; Biesbroek, G.R. Transformational Change: Governance Interventions for Climate Change Adaptation from a Continuous Change Perspective. J. Environ. Plan. Manag. 2017, 60, 558-576. [CrossRef]

5. Gillard, R.; Gouldson, A.; Paavola, J.; Van Alstine, J. Transformational Responses to Climate Change: Beyond a Systems Perspective of Social Change in Mitigation and Adaptation. Wiley Interdiscip. Rev. Clim. Chang. 2016, 7, 251-265. [CrossRef]

6. Intergovernmental Panel on Climate Change. Summary for Policymakers. In Managing the Risks of Extreme Events and Disasters to Advance Climate Change Adaptation; Cambridge University Press: Cambridge, UK, 2012. Available online: https:/ / www.ipcc.ch/report/managing-the-risks-of-extreme-events-and-disasters-toadvance-climate-change-adaptation/ (accessed on 28 September 2020).

7. McAlpine, C.; Seabrook, L.; Ryan, J.; Feeney, B.; Ripple, W.; Ehrlich, A.; Ehrlich, P. Transformational Change: Creating a Safe Operating Space for Humanity. Ecol. Soc. 2015, 20. [CrossRef]

8. Tàbara, D.J.; Jäger, J.; Mangalagiu, D.; Grasso, M. Defining Transformative Climate Science to Address High-End Climate Change. Reg. Environ. Chang. 2019, 19, 807-818. [CrossRef]

9. Bennett, N.J.; Blythe, J.; Cisneros-Montemayor, A.M.; Singh, G.G.; Sumaila, U.R. Just Transformations to Sustainability. Sustainability 2019, 11, 3881. [CrossRef]

10. Monbiot, G. Dare to Declare Capitalism Dead-Before It Takes Us All down with It. The Guardian, 25 April 2019. Available online: https:/ / www.theguardian.com/commentisfree/2019/apr/25/capitalism-economicsystem-survival-earth (accessed on 28 September 2020).

11. Savaget, P.; Geissdoerfer, M.; Kharrazi, A.; Evans, S. The Theoretical Foundations of Sociotechnical Systems Change for Sustainability: A Systematic Literature Review. J. Clean. Prod. 2019, 206, 878-892. [CrossRef]

12. Few, R.; Morchain, D.; Spear, D.; Mensah, A.; Bendapudi, R. Transformation, Adaptation and Development: Relating Concepts to Practice. Palgrave Commun. 2017, 3, 1-9. [CrossRef]

13. Kates, R.W.; Travis, W.R.; Wilbanks, T.J. Transformational Adaptation When Incremental Adaptations to Climate Change Are Insufficient. Proc. Natl. Acad. Sci. USA 2012, 109, 7156-7161. [CrossRef] [PubMed]

14. O'Brien, K. Climate Change Adaptation and Social Transformation. In International Encyclopedia of Geography; Wiley-Blackwell: Hoboken, NJ, USA, 2017. [CrossRef]

15. Brand, U.; Görg, C.; Wissen, M. Overcoming Neoliberal Globalization: Social-Ecological Transformation from a Polanyian Perspective and Beyond. Globalizations 2020, 17, 161-176. [CrossRef]

16. Waddell, S. Networking Action " Change for the Audacious: A Doer's Guide to Large Systems Change for a Flourishing Future; NetworkingAction Publishing: Boston, MA, USA, 2016.

17. Vandeventer, J.S.; Cattaneo, C.; Zografos, C. A Degrowth Transition: Pathways for the Degrowth Niche to Replace the Capitalist-Growth Regime. Ecol. Econ. 2019, 156, 272-286. [CrossRef]

18. Schmid, B. Degrowth and Postcapitalism: Transformative Geographies beyond Accumulation and Growth. Geogr. Compass 2019, 13, e12470. [CrossRef]

19. Blühdorn, I. Post-Capitalism, Post-Growth, Post-Consumerism? Eco-Political Hopes beyond Sustainability. Glob. Discourse 2017, 7, 42-61. [CrossRef]

20. Intergovernmental Panel on Climate Change. Special Report: Global Warming of 1.5 C. Geneva, Switzerland. Available online: https: / www.ipcc.ch/sr15/ (accessed on 28 September 2020).

21. IPBES. Summary for Policymakers of the Global Assessment Report on Biodiversity and Ecosystem Services of the Intergovernmental Science-Policy Platform on Biodiversity and Ecosystem Services; Technical report; IPBES Secretariat: Bonn, Germany, 2019. Available online: https://ipbes.net/global-assessment (accessed on 28 September 2020).

22. Fazey, I.; Schäpke, N.; Caniglia, G.; Patterson, J.; Hultman, J.; van Mierlo, B.; Säwe, F.; Wiek, A.; Wittmayer, J.; Aldunce, P.; et al. Ten Essentials for Action-Oriented and Second Order Energy Transitions, Transformations and Climate Change Research. Energy Res. Soc. Sci. 2018, 40, 54-70. [CrossRef]

23. Wiedmann, T.; Lenzen, M.; Keyßer, L.T.; Steinberger, J.K. Scientists' Warning on Affluence. Nat. Commun. 2020, 11, 3107. [CrossRef]

24. Boik, J.C. Science-Driven Societal Transformation, Part I: Worldview. Sustainability 2020, 12, 6881. [CrossRef] 
25. Boik, J.C. Science-Driven Societal Transformation, Part III: Design. Working Paper 0012, Principled Societies Project. 2020. Available online: https:/ /ideas.repec.org/p/psp/wpaper/0012.html (accessed on 28 September 2020).

26. CUSP. Centre for the Understanding of Sustainable Prosperity. Guildford, UK. Available online: https: //www.cusp.ac.uk/ (accessed on 28 September 2020).

27. P2P. Peer to Peer Foundation. Amsterdam, Netherlands. Available online: https://p2pfoundation.net/ (accessed on 28 September 2020).

28. Transition Network. Totnes, UK. Available online: https://transitionnetwork.org/ (accessed on 28 September 2020).

29. RIPESS. Intercontinental Network for the Promotion of Social Solidarity Economy. Available online: http: / / www.ripess.org/?lang=en (accessed on 28 September 2020).

30. AFSC. Academy for Systems Change. Burlington, VT, USA. Available online: https://www. academyforchange.org/ (accessed on 28 September 2020).

31. The Rules. Available online: https://therules.org/ (accessed on 28 September 2020).

32. Boik, J.C. First Micro-Simulation Model of a LEDDA Community Currency-Dollar Economy. Int. J. Community Curr. Res. 2014, 18, 11-29. [CrossRef]

33. Dentoni, D.; Waddell, S.; Waddock, S. Pathways of Transformation in Global Food and Agricultural Systems: Implications from a Large Systems Change Theory Perspective. Curr. Opin. Environ. Sustain. 2017, 29, 8-13. [CrossRef]

34. Blythe, J.; Silver, J.; Evans, L.; Armitage, D.; Bennett, N.J.; Moore, M.L.; Morrison, T.H.; Brown, K. The Dark Side of Transformation: Latent Risks in Contemporary Sustainability Discourse. Antipode 2018, 50, 1206-1223. [CrossRef]

35. Feola, G. Societal Transformation in Response to Global Environmental Change: A Review of Emerging Concepts. Ambio 2015, 44, 376-390. [CrossRef] [PubMed]

36. Feola, G. Capitalism in Sustainability Transitions Research: Time for a Critical Turn? Environ. Innov. Soc. Transit. 2020, 35, 241-250. [CrossRef]

37. Loorbach, D.; Frantzeskaki, N.; Avelino, F. Sustainability Transitions Research: Transforming Science and Practice for Societal Change. Annu. Rev. Environ. Resour. 2017, 42, 599-626. [CrossRef]

38. Future of Life Institute. Autonomous Weapons: An Open Letter from AI and Robotics Researchers; Future of Life Institute: Allston, MA, USA, 2015. Available online: https:/ futureoflife.org/open-letter-autonomousweapons (accessed on 28 September 2020).

39. FutureEarth. Our Future on Earth; Technical Report. Available online: https:/ / futureearth.org/publications / our-future-on-earth/ (accessed on 28 September 2020).

40. Xu, C.; Kohler, T.A.; Lenton, T.M.; Svenning, J.C.; Scheffer, M. Future of the Human Climate Niche. Proc. Natl. Acad. Sci. USA 2020, 117, 11350-11355. [CrossRef]

41. United Nations. Transforming Our World: The 2030 Agenda for Sustainable Development; 2015. Available online: https://sustainabledevelopment.un.org/content/documents/21252030\%20Agenda\% 20for\%20Sustainable\%20Development\%20web.pdf (accessed on 28 September 2020).

42. Aşıc1, A.A.; Bünül, Z. Green New Deal: A Green Way out of the Crisis? Environ. Policy Gov. 2012, 22, $295-306$. [CrossRef]

43. Bauhardt, C. Solutions to the Crisis? The Green New Deal, Degrowth, and the Solidarity Economy: Alternatives to the Capitalist Growth Economy from an Ecofeminist Economics Perspective. Ecol. Econ. 2014, 102, 60-68. [CrossRef]

44. Pollin, R. Advancing a Viable Global Climate Stabilization Project: Degrowth versus the Green New Deal. Rev. Radic. Political Econ. 2019, 51, 311-319. [CrossRef]

45. Schor, J.B.; Jorgenson, A.K. Is It Too Late for Growth? Rev. Radic. Political Econ. 2019, 51, 320-329. [CrossRef]

46. Dinerstein, E.; Vynne, C.; Sala, E.; Joshi, A.R.; Fernando, S.; Lovejoy, T.E.; Mayorga, J.; Olson, D.; Asner, G.P.; Baillie, J.E.M.; et al. A Global Deal For Nature: Guiding Principles, Milestones, and Targets. Sci. Adv. 2019, 5, eaaw2869. [CrossRef]

47. Convention on Biological Diversity, Secretariat of the Convention on Biological Diversity Montreal, Canada. Aichi Biodiversity Targets. Available online: https://www.cbd.int/sp/targets/ (accessed on 28 September 2020). 
48. Lebada, A.M. UNEP-WCMC, Partners Synthesize Approaches to Post-2020 Global Biodiversity Framework; International Institute for Sustainable Development: Winnipeg, MB, Canada, 2019. Available online: https:/ / sdg.iisd.org/news/unep-wcmc-partners-synthesize-approaches-to-post-2020-globalbiodiversity-framework/\#8208;global-biodiversity-framework/ (accessed on 28 September 2020).

49. UN News. An Important Opportunity Lost as COP25 Ends in Compromise, but Guterres Declares 'We Must Not Give Up'. UN News, 15 December 2019. Available online: https://news.un.org/en/story/2019/12/ 1053561 (accessed on 28 September 2020).

50. WMO. World Meteorological Organization Greenhouse Gas Bulletin (GHG Bulletin)-No. 13: The State of Greenhouse Gases in the Atmosphere Based on Global Observations through 2016; Technical report; WMO: Geneva, Switzerland, 2017. Available online: https:/ /library.wmo.int/index.php?lvl=notice_display\&id=20041\#.XTiXkPxOmhc (accessed on 28 September 2020).

51. United Nations Environmental Program. Emissions Gap Report; UNEP: Nairobi, Kenya, 2019. Available online: https:/ / www.unenvironment.org/resources/emissions-gap-report-2019 (accessed on 28 September 2020).

52. WMO. Multi-Agency Report Highlights Increasing Signs and Impacts of Climate Change in Atmosphere, Land and Oceans; WMO: Geneva, Switzerland, 2020. Available online: https://public.wmo.int/en/media/ press-release/multi-agency-report-highlights-increasing-signs-and-impacts-of-climate-change (accessed on 28 September 2020).

53. Jungcurt, S. CBD Analysis Shows More Efforts Needed to Achieve Aichi Biodiversity Targets; International Institute for Sustainable Development: Winnipeg, MB, Canada, 2016. Available online: http://sdg.iisd.org/ news / cbd-analysis-shows-more-efforts-needed-to-achieve\%2Daichi-biodiversity-targets / (accessed on 28 September 2020).

54. Pinheiro, H.T.; Teixeira, J.B.; Francini-Filho, R.B.; Soares-Gomes, A.; Ferreira, C.E.L.; Rocha, L.A. Hope and Doubt for the World's Marine Ecosystems. Perspect. Ecol. Conserv. 2019, 17, 19-25. [CrossRef]

55. Rounsevell, M.D.A.; Harfoot, M.; Harrison, P.A.; Newbold, T.; Gregory, R.D.; Mace, G.M. A Biodiversity Target Based on Species Extinctions. Science 2020, 368, 1193-1195. [CrossRef] [PubMed]

56. Dinerstein, E.; Olson, D.; Joshi, A.; Vynne, C.; Burgess, N.D.; Wikramanayake, E.; Hahn, N.; Palminteri, S.; Hedao, P.; Noss, R.; et al. An Ecoregion-Based Approach to Protecting Half the Terrestrial Realm. BioScience 2017, 67, 534-545. [CrossRef] [PubMed]

57. Xu, Y.; Ramanathan, V. Well below 2 C: Mitigation Strategies for Avoiding Dangerous to Catastrophic Climate Changes. Proc. Natl. Acad. Sci. USA 2017, 114, 10315-10323. [CrossRef] [PubMed]

58. Schwalm, C.R.; Glendon, S.; Duffy, P.B. RCP8.5 Tracks Cumulative $\mathrm{CO}_{2}$ Emissions. Proc. Natl. Acad. Sci. USA 2020, 117, 19656-19657. [CrossRef]

59. Williams, K.D.; Hewitt, A.J.; Bodas-Salcedo, A. Use of Short-Range Forecasts to Evaluate Fast Physics Processes Relevant for Climate Sensitivity. J. Adv. Model. Earth Syst. 2020, 12, e2019MS001986. [CrossRef]

60. Palmer, T. Short-Term Tests Validate Long-Term Estimates of Climate Change. Nature 2020, 582, $185-186$. [CrossRef]

61. Meehl, G.A.; Senior, C.A.; Eyring, V.; Flato, G.; Lamarque, J.F.; Stouffer, R.J.; Taylor, K.E.; Schlund, M. Context for Interpreting Equilibrium Climate Sensitivity and Transient Climate Response from the CMIP6 Earth System Models. Sci. Adv. 2020, 6, eaba1981. [CrossRef]

62. Jewell, J.; Cherp, A. On the Political Feasibility of Climate Change Mitigation Pathways: Is It Too Late to Keep Warming below 1.5 C? WIREs Clim. Chang. 2020, 11, e621. [CrossRef]

63. Sage, R.F. Global Change Biology: A Primer. Glob. Chang. Biol. 2020, 26, 3-30. [CrossRef]

64. Ceballos, G.; Ehrlich, P.R.; Raven, P.H. Vertebrates on the Brink as Indicators of Biological Annihilation and the Sixth Mass Extinction. Proc. Natl. Acad. Sci. USA 2020, 117, 13596-13602. [CrossRef] [PubMed]

65. Jacob, D.; Kotova, L.; Teichmann, C.; Sobolowski, S.P.; Vautard, R.; Donnelly, C.; Koutroulis, A.G.; Grillakis, M.G.; Tsanis, I.K.; Damm, A.; et al. Climate Impacts in Europe Under +1.5 C Global Warming. Earth's Future 2018, 6, 264-285. [CrossRef]

66. Strona, G.; Bradshaw, C.J.A. Co-Extinctions Annihilate Planetary Life during Extreme Environmental Change. Sci. Rep. 2018, 8, 16724. [CrossRef] [PubMed]

67. Steffen, W.; Rockström, J.; Richardson, K.; Lenton, T.M.; Folke, C.; Liverman, D.; Summerhayes, C.P.; Barnosky, A.D.; Cornell, S.E.; Crucifix, M.; et al. Trajectories of the Earth System in the Anthropocene. Proc. Natl. Acad. Sci. USA 2018, 115, 8252-8259. [CrossRef] [PubMed] 
68. Lenton, T.M.; Rockström, J.; Gaffney, O.; Rahmstorf, S.; Richardson, K.; Steffen, W.; Schellnhuber, H.J. Climate Tipping Points-Too Risky to Bet Against. Nature 2019, 575, 592-595. [CrossRef]

69. Garrett, T.J. No Way out? The Double-Bind in Seeking Global Prosperity alongside Mitigated Climate Change. Earth Syst. Dyn. 2012, 3, 1-17. [CrossRef]

70. Garrett, T.J. Long-Run Evolution of the Global Economy: 1. Physical Basis. Earth's Future 2014, 2, $127-151$. [CrossRef]

71. Zhang, H.; Vorobeychik, Y. Empirically Grounded Agent-Based Models of Innovation Diffusion: A Critical Review. arXiv 2016, arXiv:1608.08517.

72. Guilbeault, D.; Becker, J.; Centola, D. Complex Contagions: A Decade in Review. arXiv 2017, arXiv:1710.07606.

73. Kapoor, K.K.; Dwivedi, Y.K.; Williams, M.D. Rogers' Innovation Adoption Attributes: A Systematic Review and Synthesis of Existing Research. Inf. Syst. Manag. 2014, 31, 74-91. [CrossRef]

74. Rogers, E.M. Diffusion of Innovations, 4th ed.; Simon and Schuster: New York, NY, USA, 2010.

75. Robinson, C.; Dilkina, B.; Moreno-Cruz, J. Modeling Migration Patterns in the USA under Sea Level Rise. PLoS ONE 2020, 15, e0227436. [CrossRef] [PubMed]

76. Rose, J. Time To Move? Data Suggests Americans May Flee To Rural Areas Post-COVID; Forbes, 2020. Available online: https:/ /www.forbes.com/sites/jrose/2020/08/06/time-to-move-data-suggestsamericans-may-flee-to-rural-areas-post-covid/ (accessed on 28 September 2020).

77. Cash, C. Neighborhood Microgrid Gives Co-op New Case for Understanding Technology; National Rural Electric Cooperative Association: Arlington, VA, USA, 2020. Available online: https://www. electric.coop/neighborhood-microgrid-gives-co-op-new-case-for-understanding-technology/ (accessed on 28 September 2020).

78. NextDoor. San Francisco, CA, USA. Available online: https://nextdoor.com/ (accessed on 28 September 2020).

79. Perez, S. Nextdoor Adds New Funding, Closes Growth Round at \$170M with \$2.1B Valuation; Techcrunch, 2019. Available online: https://social.techcrunch.com/2019/09/10/nextdoor-adds-new-funding-from-marymeekers-bond-closes-growth-round-at-170m/ (accessed on 28 September 2020).

80. Geva, B.; Geva, D. Non-State Community Virtual Currencies. Social Science Research Network, 2019. Available online: https:/ / papers.ssrn.com/abstract=3403216 (accessed on 28 September 2020).

81. Nishibe, M. Special Feature: Evolutionary Approaches in Theory and Policy to the Diversity of Money. Evol. Inst. Econ. Rev. 2018, 15, 385-387. [CrossRef]

82. Whyte, A. The World's Largest Pension Funds Shrank in 2018. Institutional Investor, 2019. Available online: https:/ / www.institutionalinvestor.com/article/b1h02670mslhzf/The-World-s-LargestPension-Funds-Shrank-in-2018 (accessed on 28 September 2020).

83. Sardana, S. Carney Warns of Climate Change Threat to Pension Funds. Financial Times, Advisor 2019. Available online: https:/ / www.ftadviser.com/investments/2019/12/30/carney-warns-of-climate-changethreat-to-pension-funds / (accessed on 28 September 2020).

84. Shukman, D. Pressure on Big Investors to Act on Climate Change. BBC News, 27 February 2020. Available online: https:/ / www.bbc.com/news/science-environment-51657829 (accessed on 28 September 2020).

85. FairVote. Takoma Park, MD, USA. Available online: https://www.fairvote.org/ (accessed on 28 September 2020).

86. Evergreen Cooperatives Cleveland, OH, USA. Available online: http://www.evgoh.com (accessed on 28 September 2020).

87. Gölz, P.; Kahng, A.; Mackenzie, S.; Procaccia, A.D. The Fluid Mechanics of Liquid Democracy. Int. Conf. Web Internet Econ. 2018, 11316, 188-202. [CrossRef]

88. LiquidFeedback. Berlin, Germany. Available online: https://liquidfeedback.org/ (accessed on 28 September 2020).

89. Loomio. Available online: https:/ / www.loomio.org/ (accessed on 28 September 2020).

90. Hall, R.P.; Ashford, R.; Ashford, N.A.; Arango-Quiroga, J. Universal Basic Income and Inclusive Capitalism: Consequences for Sustainability. Sustainability 2019, 11, 4481. [CrossRef]

91. Bristol Pound. Bristol, UK. Available online: https:/ / bristolpound.org/ (accessed on 28 September 2020).

92. Cyclos. Utrecht, The Netherlands. Available online: https://www.cyclos.org (accessed on 28 September 2020). 
93. Goering, L. Red Cross Boosts Disaster-Prone Communities with Blockchain 'Cash'; Reuters: London, UK, 2019. Available online: https:/ / www.reuters.com/article/us-technology-aid-climate-change-idUSKBN1Y01K1 (accessed on 28 September 2020).

94. Grassroots Economics. Available online: https://www.grassrootseconomics.org (accessed on 28 September 2020).

95. Gitlab-Grassroots Economics-CIC Modeling. Available online: https:/ / gitlab.com/grassrootseconomics/ cic-modeling (accessed on 28 September 2020).

96. Rigo, A.S. Introduction: Social Currencies, Innovation and Development. IJCCR 2018, 22, 2-23. Available online: https://ijccr.net/2019/09/11/introduction-social-currencies-innovation-anddevelopment/ (accessed on 28 September 2020).

97. SEEDS. Available online: https:/ /joinseeds.com (accessed on 28 September 2020).

98. Gómez, G.M. Money as an Institution: Rule versus Evolved Practice? Analysis of Multiple Currencies in Argentina. J. Risk Financ. Manag. 2019, 12, 80. [CrossRef]

99. New Economy Colalition. Boston, MA, USA. Available online: https://neweconomy.net/ (accessed on 28 September 2020).

100. Economy for the Common Good. Available online: https://www.ecogood.org/ (accessed on 28 September 2020).

101. Next System Project. Available online: https://thenextsystem.org/ (accessed on 28 September 2020).

102. SELC. Sustainable Economies Law Center. Oakland CA, USA. Available online: https://www.theselc.org/ (accessed on 28 September 2020).

103. Wellbeing Economy Alliance. Available online: https://wellbeingeconomy.org/ (accessed on 28 September 2020).

104. Participatory Economics. Available online: https://www.participatoryeconomics.info/ (accessed on 28 September 2020).

105. Stockholm Resilience Centre. Stockholm, Sweden. Available online: https:/ /www.stockholmresilience.org/ (accessed on 28 September 2020).

106. Great Transition Initiative. Available online: https://greattransition.org/ (accessed on 28 September 2020).

107. Research and Degrowth. Available online: https://degrowth.org/ (accessed on 28 September 2020).

108. STRN. Sustainability Transitions Research Network. Available online: https://transitionsnetwork.org/ (accessed on 28 September 2020).

109. Santa Fe Institute. Santa Fe, NM, USA. Available online: https://www.santafe.edu/ (accessed on 28 September 2020).

110. NECSI. New England Complex Systems Institute. Cambridge, MA, USA. Available online: https://necsi. edu/ (accessed on 28 September 2020).

111. Servadio, J.L.; Convertino, M. Optimal Information Networks: Application for Data-Driven Integrated Health in Populations. Sci. Adv. 2018, 4, e1701088. [CrossRef]

112. SDSN. Indicators and a Monitoring Framework for the Sustainable Development Goals-Launching a Data Revolution for the SDGs; Sustainable Development Solutions Network (SDSN): New York, NY, USA, 2015. Available online: https:/ / ec.europa.eu/knowledge4policy/publication/indicators-monitoring-frameworksustainable-development/\%2Dgoals-launching-data-revolution_en (accessed on 28 September 2020).

113. Reis, B. Pope Francis: Transforming Society Positively Gives Voice to the Voiceless-Vatican News. Vatican News, 3 November 2018. Available online: https:/ / www.vaticannews.va/en/pope/news/2018-11/ pope-world-social-forum-migrants-message.html (accessed on 28 September 2020).

(c) 2020 by the author. Licensee MDPI, Basel, Switzerland. This article is an open access article distributed under the terms and conditions of the Creative Commons Attribution (CC BY) license (http://creativecommons.org/licenses/by/4.0/). 